\title{
Productivity Enhancement of Cucumber (Cucumis sativus L.) through Optimized Use of Poultry Manure and Mineral Fertilizers under Greenhouse Cultivation
}

\author{
Basheer Noman Sallam ${ }^{1,2,+}$, Tao Lu ${ }^{1,+}$, Hongjun $\mathrm{Yu}^{1, *}$, Qiang $\mathrm{Li}^{1,+}$, Zareen Sarfraz ${ }^{3}$, \\ Muhammad Shahid Iqbal ${ }^{3}\left(\mathbb{D}\right.$, Shumaila Khan ${ }^{1}$, Heng Wang ${ }^{1}$, Peng Liu ${ }^{1}$ and Weijie Jiang ${ }^{1, *}$
}

Citation: Sallam, B.N.; Lu, T.; Yu, H.; Li, Q.; Sarfraz, Z.; Iqbal, M.S.; Khan,

S.; Wang, H.; Liu, P.; Jiang, W.

Productivity Enhancement of

Cucumber (Cucumis satious L.)

through Optimized Use of Poultry

Manure and Mineral Fertilizers under Greenhouse Cultivation. Horticulturae 2021, 7, 256. https://doi.org/ 10.3390/horticulturae7080256

Academic Editors: Xun Li, Xiaohui $\mathrm{Hu}$ and Shiwei Song

Received: 9 July 2021

Accepted: 9 August 2021

Published: 20 August 2021

Publisher's Note: MDPI stays neutral with regard to jurisdictional claims in published maps and institutional affiliations.

Copyright: (c) 2021 by the authors. Licensee MDPI, Basel, Switzerland. This article is an open access article distributed under the terms and conditions of the Creative Commons Attribution (CC BY) license (https:// creativecommons.org/licenses/by/ $4.0 /)$.

1 Key Laboratory of Horticultural Crops Genetic Improvement (Ministry of Agriculture), Institute of Vegetables and Flowers, Chinese Academy of Agricultural Sciences, No.12 Zhongguancun, South Street, Haidian District, Beijing 100081, China; bns.alhakimi@gmail.com (B.N.S.); lutao@caas.cn (T.L.); liqiang05@caas.cn (Q.L.); shumaila.khan@kfueit.edu.pk (S.K.); 82101181122@caas.cn (H.W.); 82101179107@caas.cn (P.L.)

2 Department of Horticulture and Its Technologies, Faculty of Agriculture, Foods and Enviromant, Sana'a University, Sana'a P.O. Box 1247, Yemen

3 Cotton Research Institute, Chinese Academy of Agricultural Sciences, Anyang 455000, China; zskpbg@gmail.com (Z.S.); shahidkooria@gmail.com (M.S.I.)

* Correspondence: yuhongjun@caas.cn (H.Y.); jiangweijie@caas.cn (W.J.); Tel.: +86-010-8210-8797 (W.J.)

+ These authors contributed equally to this work.

\begin{abstract}
Cucumber, a widely cultivated vegetable, is mostly grown under greenhouse conditions. In recent years, the overuse of inorganic fertilizers for higher yield attainment adversely has affected human health and the environment. Therefore, a greenhouse experiment was designed to evaluate the effects of different nutrient sources (poultry manure (PM) and mineral fertilizer (MF)) on productivityenhancing parameters of cucumber via univariate and multivariate analyses. Amounts of PM and MF (NPK15:15:15) were added to coco-peat per cubic meter by weight/volume $(w / v)$ ratios as follows: $\mathrm{T}_{1}$ (control), $60 \mathrm{~kg} \mathrm{PM} ; \mathrm{T}_{2}, 30 \mathrm{~kg} \mathrm{PM}+3 \mathrm{~kg} \mathrm{MF} ; \mathrm{T}_{3}, 30 \mathrm{~kg} \mathrm{PM}+5 \mathrm{~kg} \mathrm{MF}$, and $\mathrm{T}_{4}, 30 \mathrm{~kg} \mathrm{PM}+7 \mathrm{~kg} \mathrm{MF}$. The univariate analysis performed on the collected data illustrated the significant enhancement in growth and productivity for the integrated use of PM and MF. Multivariate analyses (correlation, clustering, and Principal Component Analysis) validated the results of univariate analysis by differentiating treatments into two groups. The three treatments obtained a distinguished group from $\mathrm{T}_{1}$ (Control) and did not show significant differences among each other, with a maximum yield increase by $\mathrm{T}_{2}$ (74.6\%). According to these results, $\mathrm{T}_{2}$ could improve cucumber productivity under greenhouse conditions. It can be taken as recommendations for better quality and yield enhancement in future improvement programs and cucumber-related farming communities.
\end{abstract}

Keywords: protected greenhouse; soilless culture; poultry manure; yield enhancement; cucumber; univariate analysis; multivariate analysis

\section{Introduction}

Cucumber (Cucumis sativa L.), a member of the family Cucurbitaceae, is regarded as an essential vegetable for fresh consumption crops worldwide and is a rich source of vitamins, minerals, and antioxidants [1,2]. Cucumber is a low-calorie food, consisting of $90 \%$ water, which is why it provides superior hydration. Its eminent texture and flavor are the main reasons for its use in salads in fresh form and pickles in the processed form [3]. Its medicinal value is another distinguished property, which includes its antioxidant ability, ability to lower glycemic and antimicrobial activity, etc. Its intake regularly helps to boost metabolism and improve immunity [3]. Due to its high yields and economic value, cucumber is extensively cultivated in greenhouses in China throughout the year. Its global production in 2019 was $87,805,086$ tons on $2,231,402$ hectares of cultivated area. It is ranked 
10th among the most important vegetable crops worldwide. China shared 70,338,971 tons $(80.11 \%)$ in global production in 2019 from 1,258,370 ha (56.39\%) of cultivation area [4].

To cover rising demands, it is essential to produce a sufficient quantity of excellentquality cucumber. Several cropping obstacles prevent productivity enhancement at the desired pace, and these are responsible for restricting the healthy development of industry [5]. Finding the possibilities and increasing the pool of knowledge regarding continuous cropping obstacles are among the possibilities to develop practical approaches to overcome the issues present in long-term intensive cucumber production [6]. Cucumber is assumed to perform better with enhanced productivity under early-season crop growing and during the summer [7,8]. The optimum growth occurs between $20^{\circ} \mathrm{C}$ and $25^{\circ} \mathrm{C}$ and with growth reduction below $16^{\circ} \mathrm{C}$ or above $30^{\circ} \mathrm{C}$. Recently, cucumber cultivation in soilless mediums under controlled greenhouse conditions has become more developed and trendier around the globe than in the past [7-10]. Fertilization plays a vital role in improving soil fertility and crop yield [11,12]. Cucumber requires many nutrients for proper growth and yield.

Nitrogen, phosphorous, and potassium (NPK) are the essential nutrients for plant growth when used in optimum amounts of 15:15:15, respectively [13]. However, the improper use of fertilizers is causing severe soil degradation and limited crop productivity. Poor management of fertilizers leads to the accumulation of salt in soil aquifers. Fertilizer management should be applied in an integrated manner according to soil type, climatic factors, and crop requirements $[14,15]$. The integrated utilization of mineral and organic fertilizers can enhance soil fertility. Previous studies have reported that the integration of mineral and organic fertilizers enhances plant growth, yield, and quality. It has been reported that both organic and mineral fertilizers, when used together, led to higher nutrient uptake and increased fruit production [16-18]. It is also reported that optimum poultry manure significantly influenced the growth, yield, and nutritional quality of lettuce [19].

Due to the higher cost of inputs, commercial vegetable production has become an expensive business. One prominent cause is the availability of arable land that is declining due to extensive urbanization. Furthermore, accelerated poverty and unemployment are faced mainly in all metropolitan cities across emerging nations, which can be prevented by opting for soilless culture to grow fresh vegetables in the adjoined outskirts. Soilless cultivation is defined as the technique of growing various crops in the absence of soil used as rooting media $[20,21]$. Numerous nations have extensively adopted it during the last five decades to sustain their crop production efficiently [22,23]. Several research reports have been published regarding cucumber cultivation in soilless media under greenhouse conditions [24-30]. The current climate change situation has accelerated interest in and choice of this approach, mainly due to environmental pollution, water shortage, abrupt changes in the surrounding environment, etc. Recently, China has widely adopted this technique as the eco-organic soilless culture at the commercial level, enabling organic manures as the substrate for plant production [31,32].

This economic technique has been recommended for developing countries due to its cost-effectiveness compared to mineral solution systems [21,33]. Usage of organic materials, such as crop residues, sewage sludge, compost, and poultry manure, is well recognized as beneficial in soil resumption [18,34-36]. Keeping in view the health benefits and nutritional significance, organically produced vegetables are in high demand these days. However, there is a lack of information regarding suitable proportions of mineral and organic fertilizers required for vegetable production: excessive nitrogen fertilizers in agriculture lead to the accumulation of nitrates in plants and groundwater [15,16,37-41], thus reducing chemical fertilizers required.

The assessment and description of trait variation are essential in selecting and devising best practices to achieve productivity and quality enhancement. Furthermore, studies on variation under safeguard and decision-making are valuable in performing efficient conservation phases and avoiding redundant practices that increase production [42]. Therefore, developing procedures for both characterizing variability and reducing data size to manageable and accessible levels is essential in such studies. It is critical for agronomic 
characterization to be carried out using appropriate statistical methods. The widely used techniques include various univariate and multivariate methods such as ANOVA, mean comparison, regression, PCA, and AHC [43-45].

The main objective of the research was to assess and describe the impact of different ratios of PM and MF on the growth and productivity enhancement of cucumber crops by using univariate and multivariate analyses. The investigated fertilizer ratios or amounts can be recommended for better crop quality and yield attainment in future productivity enrichment programs and cucumber-related farming communities.

\section{Materials and Methods}

The experiment was conducted in a protected greenhouse at the Institute of Vegetables and Flowers (IVF), Soilless Culture Department, Chinese Academy of Agricultural Sciences (CAAS), during spring 2017 from February to the end of February May. The experiment followed a triplicated, completely randomized design CRD with four treatments with different substrate compositions as given Table 1 . The experiment was conducted under a protected greenhouse using troughs built of red bricks. To execute the experiment, the sand, substrate (coco-peat), poultry manure, and MF were purchased from the Hebei Lingshousi County market to execute the experiment.

Table 1. Details of four investigated treatments with their respective substrate compositions.

\begin{tabular}{cc}
\hline Treatment & Substrate Composition \\
\hline $\mathrm{T}_{1}$ (Control) & $60 \mathrm{~kg} \mathrm{~m}^{-3} \mathrm{PM}$ \\
$\mathrm{T}_{2}$ & $30 \mathrm{~kg} \mathrm{~m}^{-3} \mathrm{PM}+3 \mathrm{~kg} \mathrm{~m}^{-3} \mathrm{MF}$ \\
$\mathrm{T}_{3}$ & $30 \mathrm{~kg} \mathrm{~m}^{-3} \mathrm{PM}+5 \mathrm{~kg} \mathrm{~m}^{-3} \mathrm{MF}$ \\
$\mathrm{T}_{4}$ & $30 \mathrm{~kg} \mathrm{~m}^{-3} \mathrm{PM}+7 \mathrm{~kg} \mathrm{~m}^{-3} \mathrm{MF}$ \\
\hline
\end{tabular}

The treatments of the experiment were in each cubic substrate with $60 \mathrm{~kg} \mathrm{~m}^{-3} \mathrm{PM}\left(\mathrm{T}_{1}\right)$ used as a control, $30 \mathrm{~kg} \mathrm{~m}^{-3}$ PM plus $3 \mathrm{~kg} \mathrm{~m}^{-3} \mathrm{MF}\left(\mathrm{T}_{2}\right), 30 \mathrm{~kg} \mathrm{~m}^{-3}$ PM plus $5 \mathrm{~kg} \mathrm{~m}^{-3} \mathrm{MF}\left(\mathrm{T}_{3}\right)$, and $30 \mathrm{~kg} \mathrm{~m}^{-3}$ PM plus $7 \mathrm{~kg} \mathrm{MF}\left(\mathrm{T}_{4}\right)$.

The physicochemical properties of all substrates consisting of bulk density, air space, and porosity were evaluated according to $[2,46]$. The water-holding capacity (WHC), electrical conductivity (EC), and $\mathrm{pH}$ were measured carefully according to the methods of [47-49]. The aforementioned physico-chemical properties of sand and coco-peat utilized in this experiment are presented in Table 2.

Table 2. Some physicochemical characteristics of substrates.

\begin{tabular}{ccc}
\hline Properties & Coco-Peat & Sand \\
\hline Bulk Density $\left(\mathrm{g} \mathrm{cm}^{-3}\right)$ & 0.499 & 1.487 \\
Air Space (\%) & 20.87 & 25.01 \\
Water holding capacity (\%) & 75.7 & 27.14 \\
Total Porosity (\%) & 94.9 & 51.99 \\
Electrical Conductivity $\left(\mathrm{dS} \mathrm{m}^{-1}\right)$ & 0.207 & 0.122 \\
$\mathrm{pH}$ & 7.3 & 7.9 \\
\hline
\end{tabular}

The seedlings of cucumber (Cucumis Sativus L. cv Zhong Nong. No. 26. F1) were transplanted from the nursery to troughs at the four-leaf stage (45 days in age). Each treatment was replicated three times, and eight plants were grown as a plot. The irrigation practices were conducted daily, and fruit harvesting was carried out twice a week in the early morning. Sticky and yellow bands were used as insect control. The average relative humidity was maintained at $65 \%$. However, the temperature was maintained on an average basis at $26{ }^{\circ} \mathrm{C}$ during daytime and $16{ }^{\circ} \mathrm{C}$ during nighttime. Cooling panels and fans were installed in the greenhouse at intervals working together to keep the temperature, and relative humidity maintained and kept the environment ventilated. An automatic photoperiod adjustment system was used to adjust the optimal amount of supplemental light needed to maintain plant growth. The system automatically directs LED lights to 
be dim, brighten, and turn off throughout the day while targeting a specific daily light integral (DLI). In the current study, the photoperiod ranged between 10-12 h, and light intensity oscillated between $95-155 \mathrm{~W} \mathrm{~m}^{-2}$. Irrigation water was scheduled every week as per requirements and when needed.

The total depth of the root zone $(30 \mathrm{~cm})$ was divided into three layers, and the thickness of each layer was $10 \mathrm{~cm}$ (Figure 1). The bottom layer was coco-peat, the top layer was sand, and the middle layer was used to treat the combination of coco-peat, MF, and PM (Table 1). The poultry manure and MF $\left(\mathrm{N}-\mathrm{P}_{2} \mathrm{O}_{5}-\mathrm{K}_{2} \mathrm{O}\right.$ 15-15-15) were added well to the coco-peat based on the weight/volume $(w / v)$.

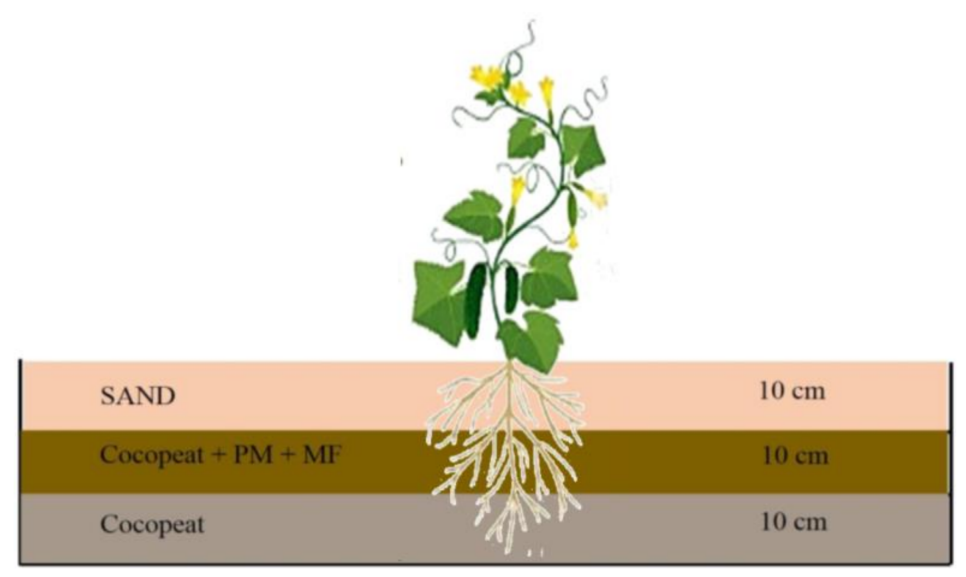

Figure 1. The schematic design three layers of the trough. The bottom layer contained coco-peat, the top layer contained sand, and the middle layer was used for different treatments of the combination of coco-peat, MF, and poultry manure (PM) except T1, which was used as control comprising only $60 \mathrm{~kg}$ of PM.

The reference level of the poultry manure $(60 \mathrm{~kg})$ was chosen based on the preliminary experiment investigating the effect of different manure levels $15,30,45,60$, and $75 \mathrm{~kg} \mathrm{~m}^{-3}$ on the yield, quality, and some growth parameters of the cucumber. According to the nitrogen $(\mathrm{N})$ content in the MF and PM, the concentration of $\mathrm{N}$ in $30 \mathrm{~kg} \mathrm{~m}^{-3}$ of poultry manure was equivalent to its concentration in $5 \mathrm{~kg}$ MF. Accordingly, $5 \mathrm{~kg}$ of MF was chosen to be combined with $30 \mathrm{~kg} \mathrm{~m}^{-3} \mathrm{PM}$ to be similar to the control of nitrogen content and different fertilizer forms. In addition, $\pm 2 \mathrm{~kg}$ of MF were added to $5 \mathrm{~kg} \mathrm{~m}^{-3}$ of MF and used in combination with PM.

Ten productivity-enhancing parameters were measured, including yield and quality parameters. Fruit yield per plant, fruit weight, leaf area, vine length, vine girth, and the number of leaves are yield traits, whereas dry matter, total soluble solids (TSS), leaf nitrogen contents, and fruit are quality traits. The data were collected from each plant in each replication, and then an average of eight plants per plot was considered for further analysis. The vine length was calculated starting from ground level until the tip of the vine with a measuring tape calibrated in centimeters, and the mean was determined for computational analysis. The vine girth was taken at $5 \mathrm{~cm}$ above the base on each sample plant using a Vernier caliper. The number of leaves from each plant was counted, and the mean value was estimated for further analysis. Leaf area was determined from three leaflets of each of the eight sampled plants based on the rectangular method. The leaflet's length and maximum width were determined from the plants' top, middle, and bottom portions.

The yield was calculated by weighing harvested fruits per plant. Fruit weight was measured at the end of experiments by analytical balance at a precision level of 0.001 (Mettler Toledo, LLC 1900 Polaris Parkway Columbus, OH 43240, USA). Dry matter and total soluble solids (TSS) were measured as indicators for fruit quality. Dry matter of the fruit $(\%)$ was obtained after the samples were dried at $60{ }^{\circ} \mathrm{C}$ until they had a constant weight. The TSS was measured by a refractometer. 
Scored data were statistically analyzed for analysis of variance ANOVA to determine significant differences $(p<0.05)$ for traits under study. Treatment means were further compared using the Tuckey (HSD) test to determine the mean differences of different treatments.

A multivariate scatterplot matrix was constructed to determine correlation coefficients by Pearson's correlation method for all the productivity-enhancing traits and quality traits investigated under study. The multivariate analyses were performed, including basic statistics, correlation analysis, Principal Component Analysis (PCA), and two-way hierarchical clustering using Agglomerative Hierarchical Clustering (AHC) approach to figure out the Euclidean distance matrix for productivity-enhancing traits of cucumber under four treatments. All the analyses were carried out using the statistical software package SAS-JMP Pro 16 (SAS Institute Inc., Cary, NC, USA, 1989-2021).

\section{Results}

One-way ANOVA for different productivity-enhancing traits, including growth, yield, and quality parameters of cucumber under soilless culture, is shown in Table 3, depicting significant differences among them under different treatments. As shown in the table, the crop's fresh fruit yield per plant was significantly affected $(p<0.05)$ by all treatments. Comparisons for all pairs using Tukey-Kramer (HSD) method were carried out and are presented in Table 4. Application of MF at the ratio of $3 \mathrm{~kg} \mathrm{~m}^{-3}\left(\mathrm{~T}_{2}\right)$ showed the highest fruit yield per plant, which is $\left(918.3 \mathrm{~g}\right.$ ) and the lowest $(525.8 \mathrm{~g})$ at $\mathrm{T}_{1}$ (control), and there is a significant difference $(p<0.05)$ between them (Figure 2A). Similarly, as shown in Figure 2B, fruit weight was significantly affected $(p<0.05)$ by all treatments compared to control. The maximum average fruit weight $(181.8 \mathrm{~g})$ was recorded at $\mathrm{T}_{3}$, while the lowest average fruits weight $(146.1 \mathrm{~g})$ was at $\mathrm{T}_{1}$ (control), and they differed significantly. In Figure 2C. Fertilizer application significantly affected $(p<0.05)$ leaf area. The maximum increase in leaf area was $658.9 \mathrm{~cm}^{2}$ for $T_{2}$. The vine length of cucumber was changed during plant growth under fertilizers treatments, as presented in Figure 2D. Significant differences $(p<0.05)$ of the treatments over the control were observed 27 days after transplant, attributed to fertilizer application. The highest increase in vine length was $202.8 \mathrm{~cm}$ for $\mathrm{T}_{3}$. Figure $2 \mathrm{E}$ revealed that the vine girth of the cucumber plant was changed during plant growth under fertilizers treatments.

Table 3. Mean Squares from One-way ANOVA for different productivity-enhancing traits of Cucumber under Soilless Culture.

\begin{tabular}{cccc}
\hline Source of Variation & Treatment & Error & Pr $(>\mathbf{F})$ \\
\hline Degree of freedom & 3 & 8 & - \\
Fruit Yield Per Plant $(\mathrm{g})$ & $94,726.2^{* *}$ & 4802.60 & 0.0005 \\
Fruit Weight $(\mathrm{g})$ & $871.007^{* *}$ & 18.9260 & $<0.0001$ \\
Leaf Area $\left(\mathrm{cm}^{2}\right)$ & $62,614.9^{* *}$ & 1692.00 & $<0.0001$ \\
Vine Length $(\mathrm{cm})$ & $611.590^{* *}$ & 41.4210 & 0.0013 \\
Vine Girth (mm) & $0.66979^{* *}$ & 0.08351 & 0.0085 \\
Number of Leaves & $9.69972^{* *}$ & 0.61650 & 0.0010 \\
Dry Matter $(\%)$ & $1.13183^{* *}$ & 0.00631 & $<0.0001$ \\
Total Soluble Solids (\%) & $0.33155^{* *}$ & 0.01271 & 0.0002 \\
N-Content (Leaf) (\%) & $6.99080^{* *}$ & 0.04253 & $<0.0001$ \\
N-Content (Fruit) $(\%)$ & $1.33254^{* *}$ & 0.01317 & $<0.0001$ \\
\hline
\end{tabular}

** Highly significant $(p<0.01)$. N-Content: Nitrogen contents; Fruit Yield Per Plant, Fruit Weight, Leaf Area, Vine Length, Vine Girth, and Number of Leaves are yield traits; Dry Matter, TSS, N-Content (Leaf), and N-Content (Fruit) are quality traits. 

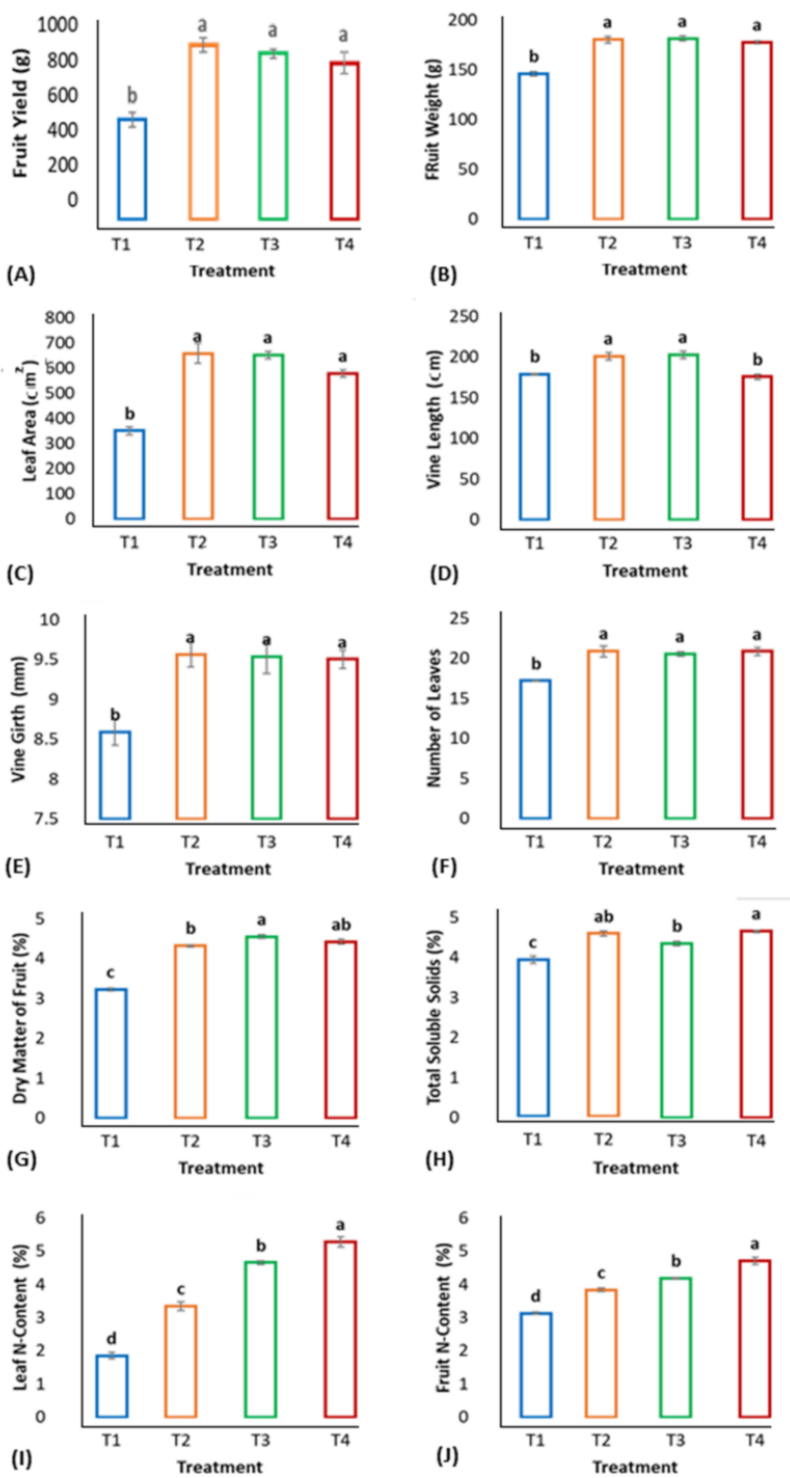

Figure 2. Graphical representation compares productivity-enhancing traits including Fruit Yield (A), Fruit Weight (B), Leaf Area (C), Vine Length (D), Vine Girth (E), Number of Leaves (F), Dry Matter (G), Total Soluble Solid (H), Leaf N-Content (I), and Fruit N-Content (J) in cucumber under soilless culture through Tukey-Kramer (HSD) test. Treatments sharing common letters revealed non-significant differences, and different letters depict significant differences $(p<0.05)$.

Table 4. Mean comparison for different productivity-enhancing traits of cucumber for different treatments under soilless culture based on Tukey-Kramer (HSD) method.

\begin{tabular}{ccccc}
\hline Traits & $\mathbf{T}_{\mathbf{1}}$ (Control) & $\mathbf{T}_{\mathbf{2}}$ & $\mathbf{T}_{\mathbf{3}}$ & $\mathbf{T}_{\mathbf{4}}$ \\
\hline Fruit Yield Per Plant (g) & $525.8 \pm 35.73 \mathrm{~b}$ & $918.3 \pm 37.36 \mathrm{a}$ & $875.7 \pm 24.3 \mathrm{a}$ & $824.7 \pm 56.04 \mathrm{a}$ \\
Fruit Weight (g) & $146.13 \pm 2.17 \mathrm{~b}$ & $180.53 \pm 3.32 \mathrm{a}$ & $181.85 \pm 2.74 \mathrm{a}$ & $177.71 \pm 1.41 \mathrm{a}$ \\
Leaf Area (cm $\left.{ }^{2}\right)$ & $350.5 \pm 14.95 \mathrm{~b}$ & $658.8 \pm 40.12 \mathrm{a}$ & $652.6 \pm 14.25 \mathrm{a}$ & $579.3 \pm 14.81 \mathrm{a}$ \\
Vine Length (cm) & $178.96 \pm 1.02 \mathrm{~b}$ & $201.13 \pm 4.89 \mathrm{a}$ & $202.8 \pm 4.2 \mathrm{a}$ & $175.77 \pm 3.55 \mathrm{~b}$ \\
Vine Girth (mm) & $8.59 \pm 0.166 \mathrm{~b}$ & $9.57 \pm 0.158 \mathrm{a}$ & $9.54 \pm 0.213 \mathrm{a}$ & $9.51 \pm 0.117 \mathrm{a}$ \\
Number of Leaves & $17.21 \pm 0.042 \mathrm{~b}$ & $20.92 \pm 0.686 \mathrm{a}$ & $20.58 \pm 0.289 \mathrm{a}$ & $20.88 \pm 0.516 \mathrm{a}$ \\
Dry Matter (\%) & $3.23 \pm 0.0382 \mathrm{c}$ & $4.33 \pm 0.0313 \mathrm{~b}$ & $4.56 \pm 0.0441 \mathrm{a}$ & $4.43 \pm 0.0635 \mathrm{ab}$ \\
Total Soluble Solids (\%) & $3.912 \pm 0.093 \mathrm{a}$ & $4.564 \pm 0.065 \mathrm{ab}$ & $4.35 \pm 0.056 \mathrm{~b}$ & $4.66 \pm 0.03 \mathrm{c}$ \\
N-Content (Leaf) (\%) & $1.849 \pm 0.098 \mathrm{~d}$ & $3.344 \pm 0.138 \mathrm{c}$ & $4.661 \pm 0.061 \mathrm{~b}$ & $5.296 \pm 0.156 \mathrm{a}$ \\
N-Content (Fruit) (\%) & $3.127 \pm 0.033 \mathrm{~d}$ & $3.84 \pm 0.064 \mathrm{c}$ & $4.187 \pm 0.023 \mathrm{~b}$ & $4.717 \pm 0.109 \mathrm{a}$ \\
\hline
\end{tabular}

Values sharing the same letters in the same row are not significantly different at $(p<0.05)$. N-Content: Nitrogen contents; Fruit Yield Per Plant, Fruit Weight, Leaf Area, Vine Length, Vine Girth, and Number of Leaves are yield traits; Dry Matter, TSS, N-Content (Leaf), and N-Content (Fruit) are quality traits. 
The highest increase in the ratio of the vine girth in comparison with the control was $9.57 \mathrm{~cm}$ for treatment $\left(\mathrm{T}_{2}\right)$. In Figure $2 \mathrm{~F}$, significant differences $(p<0.05)$ were observed for the number of leaves applying different fertilizer treatments over control. The maximum number of leaves was observed with $T_{2}$, i.e., 20.92 leaves. In Figure $2 \mathrm{G}$, the dry matter of the fruit was significantly affected $(p<0.05)$ by all treatments compared with the control. The highest value of the dry matter, which was $4.56 \%$, was obtained at $\mathrm{T}_{3}$, while the lowest value (3.41\%) was at $\mathrm{T}_{1}$ (control), and all the treatments differed significantly from control. As shown in Figure $2 \mathrm{H}$, all treatments showed a significant increase $(p<0.05)$ in the TSS of cucumber fruit over the control. The maximum increase in TSS observed was $4.66 \%$ with $\mathrm{T}_{4}$. The total nitrogen contents were determined in leaves and fruits, as shown in Figure 2I,J. The results showed that all treatments were significantly different $(p<0.05)$ for the nitrogen contents over the control in both leaves and fruits. The highest value of $\mathrm{N}$-contents in leaves and fruits, i.e., $5.296 \%$ and $4.72 \%$, respectively, was achieved by $\mathrm{T}_{4}$. The lowest values obtained for these nitrogen contents in leaves and fruits in control were $1.85 \%$ and $3.13 \%$, respectively. The estimations depicted clear and significant differences between all the investigated traits under different treatments.

The correlation matrix of productivity-enhancing traits of cucumber is presented in Figure 3. All the traits depicted a positive trend in correlation with high significance with each other. Maximum values of positive correlation were observed for dry matter with fruit weight (0.97), fruit yield per plant (0.91), and leaf area (0.91). However, vine length revealed a minimum correlation with all the yield and quality traits. The rest of the parameters represented significant positive correlations among themselves.

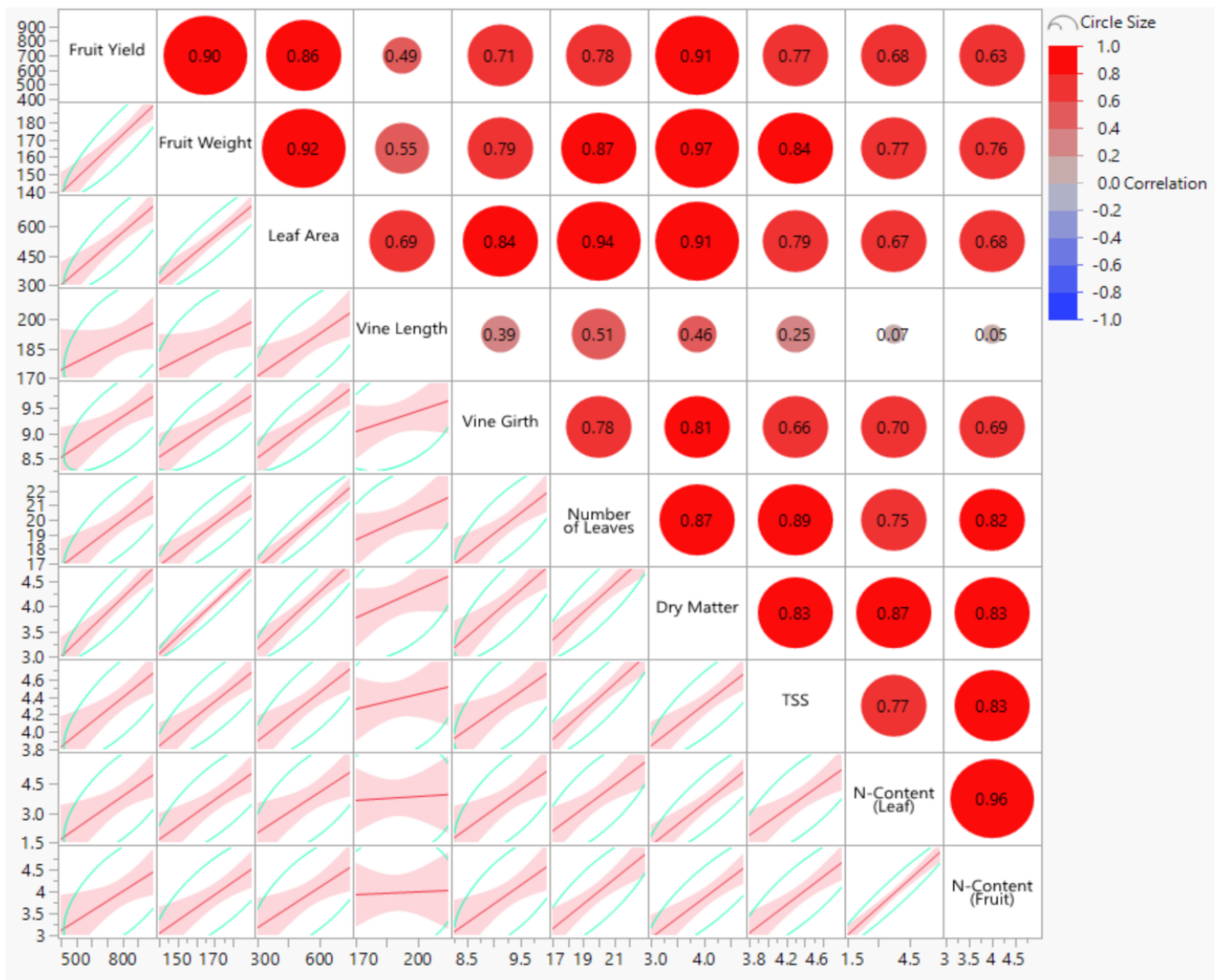

Figure 3. Scatterplot matrix for productivity—enhancing traits of cucumber under 4 treatments. The biplots of each trait with other traits showing significant relationships are presented at the lower side of the diagonal, while on the upper side, the correlation among traits under different treatments is displayed. Different shades of colors show different levels of correlation values and sizes of circles to represent the extent of correlation among these traits under treatments. 
Multivariate analysis was performed to further validate the outcome obtained from the univariate method used to distinguish the augmented treatments from conventional ones. The clustering of traits was done based on the discrimination among four treatments depicted in the form of a heat map in Figure 4. The hierarchical clustering was operated using morphological traits data from different treatments via the agglomerative approach. This approach was based on squared Euclidean distance between treatments using Ward's method. This heat plot discriminates the control $\mathrm{T}_{1}$ from the rest of the augmented treatments $T_{2}, T_{3}$, and $T_{4}$, forming two clusters. The two treatments $T_{2}$ and $T_{3}$ depicted productivity and quality-enhancing outcomes, respectively.

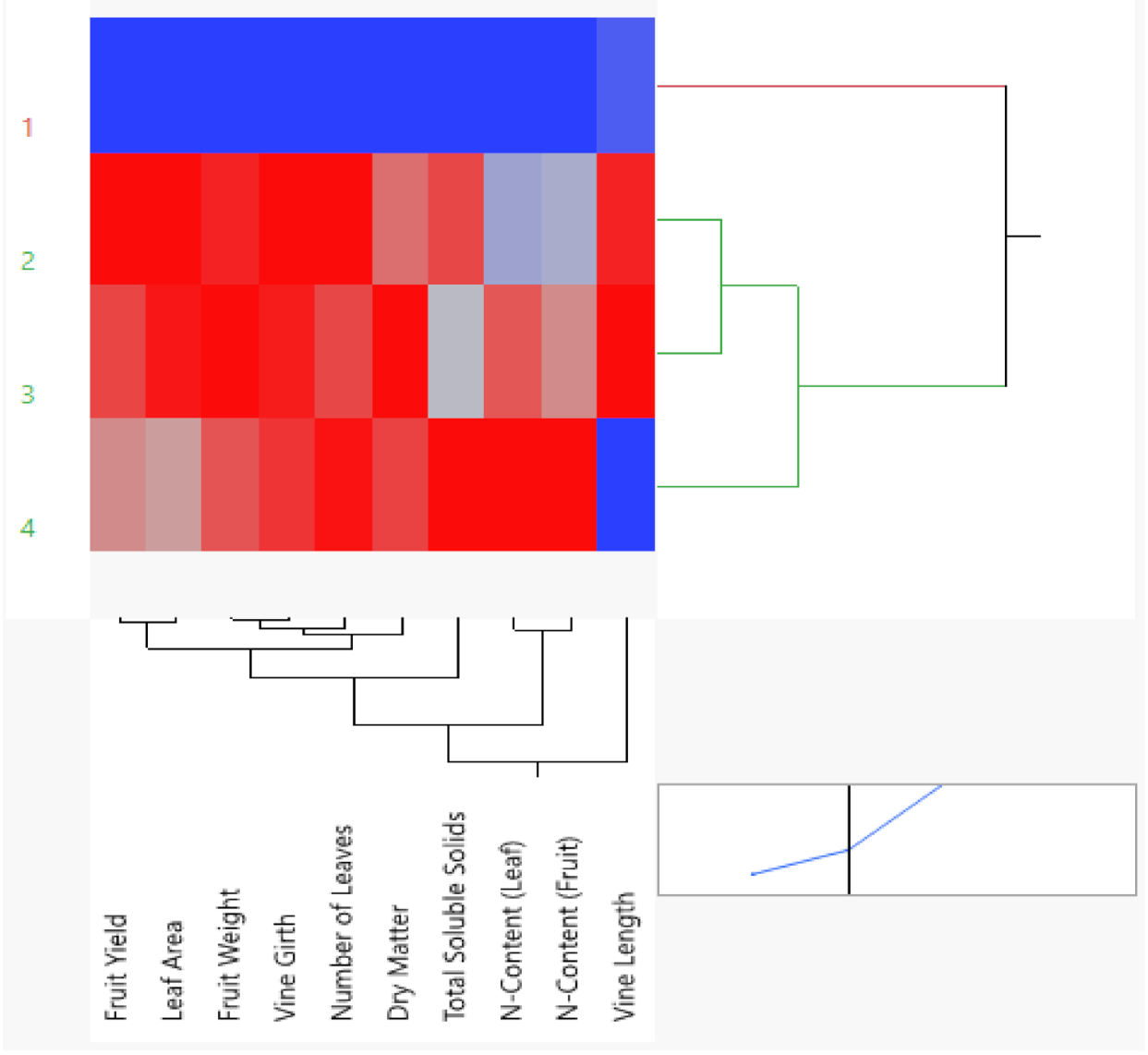

Figure 4. Two-way hierarchical clustering using Agglomerative Hierarchical Clustering (AHC) approach to figure out the Euclidean distance matrix for productivity-enhancing traits of cucumber under 4 treatments. The heat plot was assembled in JMP pro. Based on Ward's minimum variance method, V. 16 (SAS Institute Inc., Cary, NC, USA). Both the vertical and horizontal axes represent clades formation based on division related to traits under different treatments.

According to PCA, 97.5\% of the total variation was covered by the first two PCs. The Scree plot demonstrates the first two PCs with maximum coverage of $97.5 \%$ of total variation explained (Figure 5a). It was further elaborated by a factor map of squared cosines/coordinates representing long bars for variables' contribution to total variation (Figure 5b). This map chart is also validating the higher contribution of PC1 and PC2. Moreover, the distribution details related to traits and treatments covered by the first two PCs were revealed in the Biplot matrix (Figure 6). It validates clear discrimination of Control $\mathrm{T}_{1}$ from the rest of the augmented treatments $\mathrm{T}_{2}, \mathrm{~T}_{3}$, and $\mathrm{T}_{4}$. 


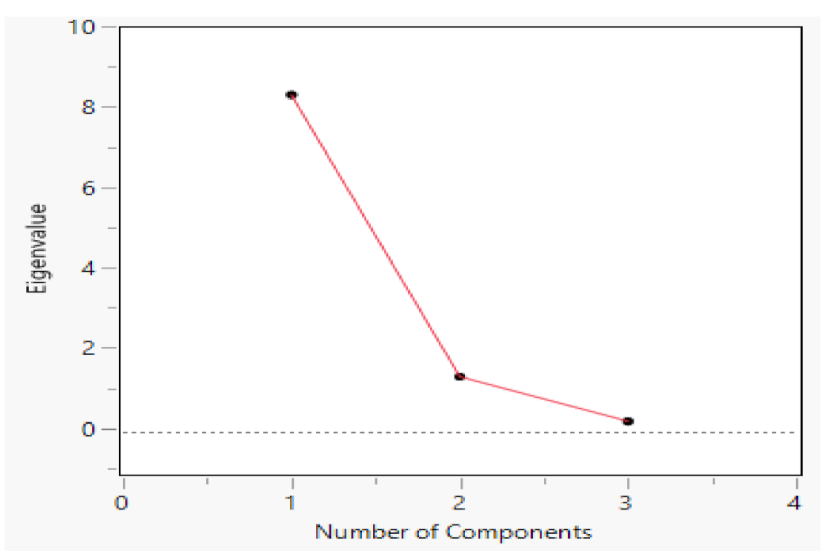

(a)

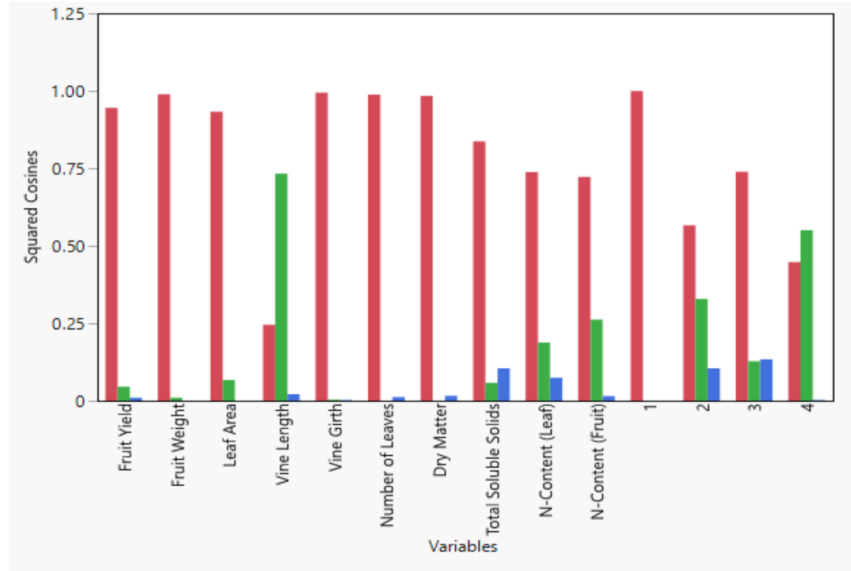

(b)

Figure 5. (a) Scree plot reveals the number of components covering sufficient variation related to treatments used for investigated traits. (b) Squared cosines associated with the principal components for ten investigated traits and four treatments.

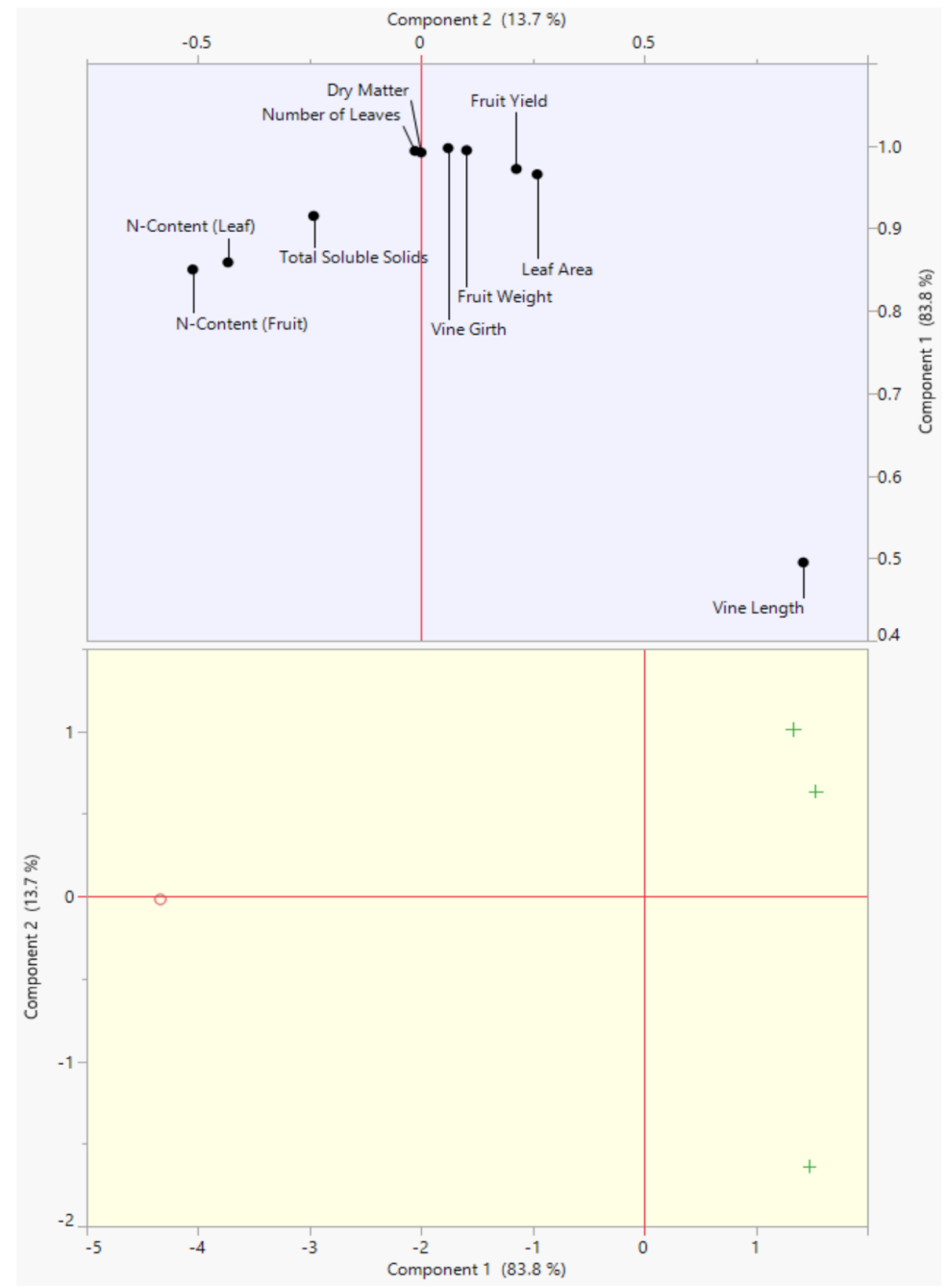

Figure 6. Biplot matrix for principal component analysis revealing the distribution of traits in question under treatments. The upper half of the matrix represents traits, while the lower half depicts treatments placed at different places of the scatterplot. 


\section{Discussion}

Findings of the current study, which was executed to examine the effects of different fertilizer treatments as compared to conventional application of fertilizers under soilless culture, have demonstrated that application of PM combined with MF had a significant effect on the cucumber production by the increase in yield and vegetative growth [50]. It is also evident that we can benefit from poultry manure application, especially improvement in fruit quality resulting from nutrient uptake, increasing organic matter content, and enhancing the activity of microorganisms [51-54]. These nutrients increase vegetative growth and form a robust radical total, thus increasing the number of leaves and vine length. These results agree with previous studies. Increasing amounts of manures in treatments have positively influenced all the traits. Such findings were previously reported by Hamma et al. [55] and Law-Ogbowo [56]. Compared to untreated (control) ones, the highest number of leaves observed for treated cucumber plants, compared to untreated (control) ones, indicated higher nutrient uptake, which ultimately gave rise to a higher leaf area. Higher leaf area was an apparent cause of maximum light interception. Wider leaf area is necessary for maximum light interception for increased photosynthesis and transpiration [57], leading to improved production/yield due to higher translocation of assimilates to the storage organ, i.e., fruit [56].

The application of MF and PM improved the cucumber's growth characteristics, which triggered an increase in the average weight of fruit and net yield. This result agrees with previous works $[16,18,21,58-60]$. The quality of cucumber fruits was enhanced by mineral contents, dry matter, and total soluble solids. The improvement in the fruit quality of cucumber could mainly be attributed to the combined use of organic and MF. Furthermore, the improved growth of plants under study positively responds to the balanced discharge of additional nutrient elements through moisture made available by applying PM and coco-peat. These findings were also confirmed by previous studies $[33,51,55,58]$.

Among the treatments where poultry manure at $30 \mathrm{~kg} \mathrm{~m}^{-3}$ was combined with MF, the results showed no significant differences. The application of MF was found to increase the growth and yield parameters significantly over the control. However, only minor variations were observed among these treatments. The possible reason could be the slight variation in the dosage of MF, where 3, 5 , and $7 \mathrm{~kg} \mathrm{~m}^{-3}$ NPK were applied to T2, T3, and $\mathrm{T} 4$, respectively. It is also likely that the crop met the nutrient requirement from the poultry manure combined with the lowest level of NPK. Therefore, more applications of MF might not have significant effects on the measured parameters. Sometimes the overdose of fertilizer negatively affects some parameters [12,61]. For instance, the overdose of nitrogen could prolong the growth stage and delay the fruiting stage. As shown in Figure 2, the total yield among $\mathrm{T}_{2}, \mathrm{~T}_{3}$, and $\mathrm{T}_{4}$ has slightly decreased as a function of NPK increase. Although the decrease in yield was insignificant, it indicates the negative effect of the overuse of MF on the crop. Our findings are consistent with the previously reported studies $[15,56,61-64]$.

The correlation of parameters investigated with each other represented in Figure 3 depicts a significant positive correlation. All the traits except vine length significantly depend on each other for better performance [65]. All the quality parameters positively correlate with yield parameters and ultimately increase the net yield [66,67]. Maximum correlations were observed for dry matter with fruit yield per plant, fruit weight, and leaf area. This indicates the interdependence of dry fruit matter on traits under study contributing to yield. Our findings follow those of previous studies [42,65,68-71].

Both PCA and AHC multivariate methods are widely adopted today to cluster and represent closeness or distances between variables in the dataset [72]. The visual display of variables data is plotted as factors acquired through the PCA approach [73]. In this study, the first two PCs represented maximum coverage of variation. The AHC method divided the treatments into two distinct clusters, revealing control $\mathrm{T} 1$ as discriminant from the rest. The two clusters formation confirms different effects of conventional amount of manure used from augmented amounts used in the study. It was observed that the 
augmented amounts have a better impact on the productivity and quality of the fruit traits. The T2 improved the productivity traits, while T3 helped to enhance quality traits more. Both univariate and multivariate analysis methods provided the grounds to support the hypothesis that the treatments used on traits were sufficient to cover maximum variation. Similar findings are reported in the study [43].

\section{Conclusions}

Presently, production of cucumber is dependent mainly on chemical fertilizers which have adverse effects on human health and surrounding environments. This study demonstrated the better and safe use of PM and MF at various combination ratios on cucumber crop. The vegetative growth and yield productivity of the crop were significantly enhanced with organic fertilizer application. The results did not show significant differences between the three experimental mineral fertilizer ratios combined with poultry manure. Hence, the lowest ratio could be recommended as best to achieve better quality and growth. The obtained results can be used as future recommendations in crop cultivation programs focusing on productivity and quality enhancement and the global farming community under soilless cultures of cucumber.

Author Contributions: Conceptualization, W. J, B.N.S.; methodology, H.Y. and B.N.S.; software, B.N.S., Z.S., M.S.I. and S.K.; validation, B.N.S., Z.S. and M.S.I.; formal analysis, B.N.S., M.S.I. and Z.S.; investigation, B.N.S.; data curation, B.N.S.; writing original draft preparation, B.N.S. and Z.S.; writing review and editing, B.N.S., M.S.I., H.W., P.L., T.L. and Q.L.; visualization, B.N.S., M.S.I. and Z.S.; supervision, W.J.; project administration, H.Y.; funding acquisition, W.J.; All authors have read and agreed to the published version of the manuscript.

Funding: This research was financially supported by China's National Key R\&D Program 2019YFD1001901, National Key R\&D Program of China, 2019YFD1000300, and National Natural Science Foundation of China, 32002115.

Institutional Review Board Statement: Not applicable.

Informed Consent Statement: Not applicable.

Data Availability Statement: Data supporting reported results will be available and provided at reasonable request.

Conflicts of Interest: The authors declare no conflict of interest.

\section{References}

1. Patel, C.; Panigrahi, J. Starch glucose coating-induced postharvest shelf-life extension of cucumber. Food Chem. 2019, 288, 208-214. [CrossRef]

2. Hao, J.; Li, Q.; Yu, H.; Wang, H.; Chai, L.; Miao, T.; Jiang, W. Comparative proteomic analysis of cucumber fruits under nitrogen deficiency at the fruiting stage. Hortic. Plant J. 2020, 7, 59-72. [CrossRef]

3. Sharma, V.; Sharma, L.; Sandhu, K.S. Cucumber (Cucumis sativus L.); Springer: Singapore, 2020; pp. 333-340.

4. FAOSTAT. Food and Agriculture Organization of the United Nations. Crop. Prod. Data 2021. Available online: http://www.fao. org /faostat/en/\#data (accessed on 9 July 2021).

5. Lei, T.L.; Yang, L.J. Overcoming Continuous Cropping Obstacles \& mdash: The Difficult Problem. Sci. Agric. Sin. 2016, 49, 916-918. [CrossRef]

6. Liu, X.; Li, Y.; Ren, X.; Chen, B.; Zhang, Y.; Shen, C.; Wang, F.; Wu, D. Long-Term Greenhouse Cucumber Production Alters Soil Bacterial Community Structure. J. Soil Sci. Plant. Nutr. 2020, 20, 306-321. [CrossRef]

7. Meena, R.K.; Trivedi, S.; Kumar, M. Protected Cultivation Vegetable: Cucumber. Biot. Res. Today 2020, 2, $359-361$.

8. Singh, M.C.; Singh, J.; Pandey, S.; Mahay, D.; Srivastava, V. Factors Affecting the Performance of Greenhouse Cucumber Cultivation: A Review. Int. J. Curr. Microbiol. Appl. Sci 2017, 6, 2304-2323. [CrossRef]

9. Ghehsareh, A.M.; Khosravan, S.; Shahabi, A.A. The effect of different nutrient solutions on some growth indices of greenhouse cucumber in soilless culture. J. Plant. Breed. Crop. Sci. 2011, 3, 321-326.

10. Nikolaou, G.; Neocleous, D.; Kitta, E.; Katsoulas, N. Advances in irrigation/fertigation techniques in greenhouse soilless culture systems (SCS). In Advances in Horticultural Soilless Culture; Burleigh Dodds Science Publishing: Cambridge, UK, 2021 ; pp. 249-275.

11. Yang, Y.; Wang, P.; Zeng, Z. Dynamics of bacterial communities in a 30-year fertilized paddy field under different organicinorganic fertilization strategies. Agronomy 2019, 9, 14. [CrossRef] 
12. Lu, J.; Yang, R.; Wang, H.; Huang, X. Stress effects of chlorate on longan (Dimocarpus longan Lour.) trees: Changes in nitrogen and carbon nutrition. Hortic. Plant J. 2017, 3, 237-246. [CrossRef]

13. Umekwe, P.; Okpani, F.; Okocha, I. Effects of different rates of NPK 15: 15: 15 and pruning methods on the growth and yield of cucumber (Cucumis sativus L.) in Unwana-Afikpo. IJSR 2015, 4, 36-39.

14. Johnston, A. Food security in the WANA region, the essential need for balanced fertilization. In International Workshop Proceedings, Ege University, Izmir, Turkey; International Potash Institute (IPA): Basel, Switzerland, 1997.

15. Singh, M.C.; Kachwaya, D.S.; Kalsi, K. Soilless cucumber cultivation under protective structures in relation to irrigation coupled fertigation management, economic viability and potential benefits-a review. Int. J. Curr. Microbiol. Appl. Sci. 2018, 7, $2451-2468$. [CrossRef]

16. O'Brien, T.A.; Barker, A.V. Growth of peppermint in compost. J. Herbs Spices Med. Plants 1996, 4, 19-27. [CrossRef]

17. Natsheh, B.; Mousa, S. Effect of organic and inorganic fertilizers application on soil and cucumber (Cucumis sativa L.) plant productivity. Int. J. Agric. For. 2014, 4, 166-170.

18. Agegnehu, G.; Bass, A.M.; Nelson, P.N.; Bird, M.I. Benefits of biochar, compost and biochar-compost for soil quality, maize yield and greenhouse gas emissions in a tropical agricultural soil. Sci. Total Environ. 2016, 543, 295-306. [CrossRef]

19. Masarirambi, M.T.; Dlamini, P.; Wahome, P.K.; Oseni, T.O. Effects of chicken manure on growth, yield and quality of lettuce (Lactuca sativa L.)'Taina'under a lath house in a semi-arid sub-tropical environment. Agric. Environ. Sci. 2012, 12, 399-406.

20. Ganeshamurthy, A.; Kalaivanan, D.; Selvakumar, G.; Panneerselvam, P. Nutrient management in horticultural crops. Indian J. Fertil. 2015, 11, 30-42.

21. Singh, M.; Singh, A.; Singh, J.; Singh, K. Economic viability of soilless cucumber cultivation under naturally ventilated greenhouse conditions. Indian J. Hortic. 2020, 77, 315-321. [CrossRef]

22. Barrett, G.; Alexander, P.; Robinson, J.; Bragg, N. Achieving environmentally sustainable growing media for soilless plant cultivation systems-A review. Sci. Hortic. 2016, 212, 220-234. [CrossRef]

23. Schmilewski, G. Growing medium constituents used in the EU. In Proceedings of the International Symposium on Growing Media, Nottingham, UK, 2-9 September 2007; pp. 33-46.

24. Huber, J.; Zheng, Y.; Dixon, M. Hydroponic cucumber production using urethane foam as a growth substrate. Acta Hortic. 2005, 697, 139. [CrossRef]

25. Gul, A.; Engindeniz, S.; Aykut, N. Can closed substrate culture be an alternative for small-scale farmers? Acta Hortic. 2007, 747, 83. [CrossRef]

26. Janapriya, S.; Palanisamy, D.; Ranghaswami, M. Soilless media and fertigation for naturally ventilated polyhouse production of cucumber (Cucumis sativus L.) CV Green Long. Int. J. Agric. Environ. Biotechnol. 2010, 3, 199-205.

27. Zhang, R.-H.; Zeng-Qiang, D.; Zhi-Guo, L. Use of spent mushroom substrate as growing media for tomato and cucumber seedlings. Pedosphere 2012, 22, 333-342. [CrossRef]

28. Mazahreh, N.; Nejatian, A.; Mousa, M. Effect of different growing medias on cucumber production and water productivity in soilless culture under UAE conditions. Merit Res. J. Agric. Sci. Soil Sci. 2015, 3, 131-138.

29. Singh, M.C.; Singh, J.; Singh, K. Optimal operating microclimatic conditions for drip fertigated cucumbers in soilless media under a naturally ventilated greenhouse. Indian J. Ecol. 2017, 44, 821-826.

30. Gruda, N.S.; Bragg, N. Developments in alternative organic materials for growing media in soilless culture systems. In Advances in Horticultural Soilless Culture; Burleigh Dodds Science Publishing: Cambridge, UK, 2021; pp. 73-106.

31. Gül, A.; Kıdoğlu, F.; Anaç, D. Effect of nutrient sources on cucumber production in different substrates. Sci. Hortic. 2007, 113, 216-220. [CrossRef]

32. RONG, Q.-L.; LI, R.-N.; HUANG, S.-W.; TANG, J.-W.; ZHANG, Y.-C.; WANG, L.-Y. Soil microbial characteristics and yield response to partial substitution of chemical fertilizer with organic amendments in greenhouse vegetable production. J. Integr. Agric. 2018, 17, 1432-1444. [CrossRef]

33. Xing, Y.; Meng, X. Development and prospect of hydroponics in China. In Proceedings of the International Symposium on Growing Media and Hydroponics, Windsor, ON, Canada, 19-26 May 1997; pp. 753-760.

34. Tejada, M.; Gonzalez, J.; García-Martínez, A.; Parrado, J. Application of a green manure and green manure composted with beet vinasse on soil restoration: Effects on soil properties. Bioresour. Technol. 2008, 99, 4949-4957. [CrossRef] [PubMed]

35. Opara, E.C.; Zuofa, K.; Isirimah, N.; Douglas, D. Effects of poultry manure supplemented by NPK 15: 15: 15 fertilizer on cucumber (Cucumis sativus L.) production in Port Harcourt (Nigeria). Afr. J. Biotechnol. 2012, 11, 10548-10554. [CrossRef]

36. Bowles, T.M.; Acosta-Martínez, V.; Calderón, F.; Jackson, L.E. Soil enzyme activities, microbial communities, and carbon and nitrogen availability in organic agroecosystems across an intensively-managed agricultural landscape. Soil Biol. Biochem. 2014, 68, 252-262. [CrossRef]

37. Havlin, J.; Beaton, J.; Tisdale, S.; Nelson, W. Soil acidity and alkalinity. Soil Fertil. Fertil. Pearson Prentice Hall. 2005, 7, 45-96.

38. Ju, X.-T.; Xing, G.-X.; Chen, X.-P.; Zhang, S.-L.; Zhang, L.-J.; Liu, X.-J.; Cui, Z.-L.; Yin, B.; Christie, P.; Zhu, Z.-L. Reducing environmental risk by improving $\mathrm{N}$ management in intensive Chinese agricultural systems. Proc. Natl. Acad. Sci. USA 2009, 106, 3041-3046. [CrossRef] [PubMed]

39. Shen, W.; Lin, X.; Shi, W.; Min, J.; Gao, N.; Zhang, H.; Yin, R.; He, X. Higher rates of nitrogen fertilization decrease soil enzyme activities, microbial functional diversity and nitrification capacity in a Chinese polytunnel greenhouse vegetable land. Plant Soil 2010, 337, 137-150. [CrossRef] 
40. Zhen, Z.; Liu, H.; Wang, N.; Guo, L.; Meng, J.; Ding, N.; Wu, G.; Jiang, G. Effects of manure compost application on soil microbial community diversity and soil microenvironments in a temperate cropland in China. PLoS ONE 2014, 9, e108555. [CrossRef]

41. Rashti, M.R.; Wang, W.; Moody, P.; Chen, C.; Ghadiri, H. Fertiliser-induced nitrous oxide emissions from vegetable production in the world and the regulating factors: A review. Atmos. Environ. 2015, 112, 225-233. [CrossRef]

42. Singh, J.; Singh, M.K.; Kumar, M.; Kumar, V.; Singh, K.P.; Omid, A.Q. Effect of integrated nutrient management on growth, flowering and yield attributes of cucumber (Cucumis sativus L.). Int. J. Chem. Stud. 2018, 6, 567-572.

43. Lotti, C.; Marcotrigiano, A.R.; De Giovanni, C.; Resta, P.; Ricciardi, A.; Zonno, V.; Fanizza, G.; Ricciardi, L. Univariate and multivariate analysis performed on bio-agronomical traits of Cucumis melo L. germplasm. Genet. Resour. Crop. Evol. 2008, 55, 511-522. [CrossRef]

44. Khan, A.; Erum, S.; Riaz, N.; Shinwari, M.I.; Ibrar Shinwari, M. Multivariate Analysis of Potato Genotypes for Genetic Diversity. bioRxiv 2020. [CrossRef]

45. Mangi, N.; Nazir, M.F.; Wang, X.; Iqbal, M.S.; Sarfraz, Z.; Jatoi, G.H.; Mahmood, T.; Ma, Q.; Shuli, F. Dissecting Source-Sink Relationship of Subtending Leaf for Yield and Fiber Quality Attributes in Upland Cotton (Gossypium hirsutum L.). Plants 2021, 10, 1147. [CrossRef]

46. de Boodt, M.; Verdonck, O. The physical properties of the substrates in horticulture. In Proceedings of the III Symposium on Peat in Horticulture, Dublin, Ireland, 28 June-3 July 1971; pp. 37-44.

47. Brown, E. Physical and chemical properties of media component of milled pine bark and sand. J. Am. Soc. Hort. Sci. 1975, 100, 119-121.

48. Wilkinson, K.M.; Landis, T.D.; Haase, D.L.; Daley, B.F.; Dumroese, R.K. Tropical nursery manual: A guide to starting and operating a nursery for native and traditional plants. Agric. Handb. Wash. DC US Dep. Agric. For. Serv. 2014, $732,376$.

49. Kim, S.; Abinaya, M.; Park, Y.; Jeong, B. Physiological and biochemical modulations upon root induction in rose cuttings as affected by growing medium. Hortic. Plant J. 2018, 4, 257-264. [CrossRef]

50. He, M.; Chen, Z.; Sakurai, K.; Iwasaki, K.; Shen, Y.; Zhou, J. Effect of differences in substrate formulations on cucumber growth under soilless bag culture in greenhouse. Soil Sci. Plant. 2003, 49, 763-767. [CrossRef]

51. Agele, S. Growth and yield of tomato grown on degraded soil amended with organic wastes. In Proceedings of the 35th Conference of the Agricultural Society of Nigeria, Federal University of Agriculture, Abeokuta, Nigeria, 14-17 March 2001; pp. 151-154.

52. Ghosh, P.; Bandyopadhyay, K.; Manna, M.; Mandal, K.; Misra, A.; Hati, K. Comparative effectiveness of cattle manure, poultry manure, phosphocompost and fertilizer-NPK on three cropping systems in vertisols of semi-arid tropics. II. Dry matter yield, nodulation, chlorophyll content and enzyme activity. Bioresour. Technol. 2004, 95, 85-93. [CrossRef]

53. Ayoola, O.; Adeniyan, O. Influence of poultry manure and NPK fertilizer on yield and yield components of crops under different cropping systems in south west Nigeria. Afr. J. Biotechnol. 2006, 5, 1386-1392.

54. Adekiya, A.; Agbede, T. Growth and yield of tomato (Lycopersicon esculentum Mill) as influenced by poultry manure and NPK fertilizer. Emir. J. Food Agric. 2009, 21, 10-20.

55. Hamma, I.; Ibrahim, U.; Haruna, M. Effect of poultry manure on the growth and yield of cucumber (Cucumis sativum L.) in Samaru, Zaria. Niger. J. Agric. Food Environ. 2012, 8, 94-98.

56. Law-Ogbomo, K.E.; Osaigbovo, A.U. Growth and yield responses of cucumber (Cucumis sativum L.) to different nitrogen levels of goat manure in the humid ultisols environment. Not. Sci. Biol. 2018, 10, 228-232. [CrossRef]

57. Ma, L.; Gardner, F.; Selamat, A. Estimation of leaf area from leaf and total mass measurements in peanut. Crop. Sci. 1992, 32, 467-471. [CrossRef]

58. Okoli, P.; Nweke, I. Effect of poultry manure and mineral fertilizer on the growth performance and quality of cucumber fruits. $J$. Exp. Biol. Agric. Sci. 2015, 3, 362-367.

59. Ewulo, B.; Ojeniyi, S.; Akanni, D. Effect of poultry manure on selected soil physical and chemical properties, growth, yield and nutrient status of tomato. Afr. J. Agric. Res. 2008, 3, 612-616.

60. Vo, M.; Wang, C. Effects of manure composts and their combination with inorganic fertilizer on acid soil properties and the growth of muskmelon (Cucumis melo L.). Compost. Sci. Util. 2015, 23, 117-127. [CrossRef]

61. Singh, M.C.; Singh, K.G.; Singh, J.P. Interactive Effects of Fertigation and Varieties on Pant Growth Attributes and Yield of Soilless Cucumbers. Int. J. Sci. Technol. Soc. 2020, 8, 50.

62. Kim, T.Y.; Lee, S.H.; Ku, H.; Lee, S.Y. Enhancement of Drought Tolerance in Cucumber Plants by Natural Carbon Materials. Plants 2019, 8, 446. [CrossRef]

63. Fields, J.S.; Gruda, N.S. Developments in inorganic materials, synthetic organic materials and peat in soilless culture systems. In Advances in Horticultural Soilless Culture; Burleigh Dodds Science Publishing: Cambridge, UK, 2021; pp. 45-72.

64. Tüzel, Y.; Balliu, A. Advances in liquid-and solid-medium soilless culture systems. In Advances in Horticultural Soilless Culture; Burleigh Dodds Science Publishing: Cambridge, UK, 2021; pp. 213-248.

65. Saeed, H.; Waheed, A. A Review on Cucumber. Int. J. Technol. Res. Sci. 2017, 2, 402-405.

66. Kumar, S.; Kumar, R.; Gupta, R.; Sephia, R. Studies on correlation and path coefficient analysis for yield and its contributing traits in cucumber. Crop. Improv. 2011, 38, 18-23.

67. Monna, M.N.A.; Robin, A.B.M.A.H.K.; Rabbani, M.G. Genetic variability, correlation and path analysis of Cucumber (Cucumis sativus L.). Bangladesh J. Agril. Sci. 2006, 33, 81-84. 
68. Lakshmi, L.; Reddy, S. Studies on correlation and path-coefficient analysis for yield and its contributing characters in Cucumber (Cucumis sativus L.). IJCS 2018, 6, 1649-1653.

69. Ullah, M.; Hasan, M.; Chowdhury, A.; Saki, A.; Rahman, A. Genetic variability and correlation in exotic cucumber (Cucumis sativus L.) varieties. Bangladesh J. Plant. Breed. Genet. 2012, 25, 17-23. [CrossRef]

70. Hasan, R.; Hossain, M.K.; Alam, N.; Bashar, A.; Islam, S.; Tarafder, M.J.A. Genetic divergence in commercial cucumber (Cucumis sativus L.) genotypes. Bangladesh J. Bot. 2015, 44, 201-207. [CrossRef]

71. Arunkumar, K.; Ramanjinappa, V.; Ravishankar, M. Path coefficient analysis in F2 population of cucumber (Cucumis sativuus L.). Plant Arch. 2011, 11, 471-474.

72. Lee, I.; Yang, J. Common clustering algorithms. In Comprehensive Chemometrics: Chemical and Biochemical Data Analysis; Elsevier: Oxford, UK, 2009; pp. 577-618.

73. Xu, Q.; Liu, J.-S.; Chen, X.-H.; Li, L.-L.; Go, S.-G.; Chen, Z.-M.; Xiao, J.; Cao, B.-S. Principal Component and Cluster Analysis of Quality Characters of Pickling Cucumber (Cucumis sativus L.). J. Yandzhou Univ. 2003, 4, 78-81. 